\title{
GEOGRAPHICAL EXTENSION OF FREE TRADE ZONES AS TRADE LIBERALIZATION: A NUMERICAL SIMULATION APPROACH
}

\author{
CHI-YUNG NG \\ JOHN WHALLEY
}

CESIFO WORKING PAPER NO. 1147

CATEgORY 7: TRAde Policy

MARCH 2004

\footnotetext{
An electronic version of the paper may be downloaded

- from the CESifo website: www.CESifo.de
} 


\title{
GEOGRAPHICAL EXTENSION OF FREE TRADE ZONES AS TRADE LIBERALIZATION: A NUMERICAL SIMULATION APPROACH
}

\begin{abstract}
We consider progressive geographical expansion of free trade zones within countries as a form of trade liberalization and compare observationally equivalent liberalization involving changes in the coverage of a free trade zone for a fixed tariff rate, and tariff reductions applying to all trade if there are no free trade zones in the country (in the sense of generating similar changes in trade volumes). Our work is motivated by China's approach to service trade liberalization in banking and other areas of progressive additions of cities to automatic licence treatment for foreign entities. We use numerical simulation methods to compare conventional national tariff reductions to trade liberalization achieved through the geographical expansion of free trade zones in terms of welfare impacts. Either the size of the free trade zone with a fixed tariff, or the tariff rate given the size of the free trade zone can be endogenously determined so as to yield observational equivalence in the sense of trade volume impacts across trade policy changes. Numerical results overwhelmingly indicate larger welfare costs from imposing geographically restrictive schemes since a higher tariff applies to a smaller fraction of trade, and distortions within country trade also apply. Numerical policy analyses using a conventional tariff-equivalent ad valorem modeling approach to evaluate the impacts of liberalizing geographical barriers can thus be highly misleading. We explore both pure exchange and with production cases, and relate our discussion to earlier literature on free trade zones.
\end{abstract}

JEL classification: F13, F17.

Chi-Yung Ng

University of Western Ontario

Dept. of Economics

London, Ontario

Canada, N6A 5C2

\author{
John Whalley \\ University of Western Ontario \\ Dept. of Economics \\ London, Ontario \\ Canada, N6A 5C2 \\ jwhalley@uwo.ca
}

We are grateful to SSHRC for academic support, and to M.Y. Liang, J. Macgee, and T. Sicular for comments on an earlier draft. 


\section{Introduction}

This paper analyses the geographical extension of preexisting free trade zones as trade liberalization, and assesses how it compares to more conventional trade liberalization involving the lowering of a national tariff. We assume that countries exist (China being one example) where it is administratively feasible to operate movable internal trade barriers, and further assume that some mechanism exists for the progressive enlargement of free trade zones within countries. This can be through the sequential addition of cities or portions of an economy to a preexisting free trade (or export processing) zone. Given the present administrative structure in China, we assume that such schemes are possible to implement even though in reality they may be hard to administer. Vietnam and other countries with strong administrative control mechanisms and embedded provincial structures also seem to fit this characterization.

The paper is motivated by the form that progressive liberalization will take during the implementation period for China's WTO accession commitments in key service areas such as banking, insurance, and telecoms. ${ }^{2}$ For these service items, protection through a tariff is not feasible as there is no customs clearance for international trade in the relevant service. Prior to WTO accession, China's domestic markets in these areas are protected by regulatory arrangements which rely on licences and limits on the extent of foreign participation (typically, the degree of ownership in joint ventures). Since licences are inherently discrete instruments of protection, they have effectively been converted into continuous instruments of progressive liberalization in these service areas by allowing for an expansion in their geographical coverage over the five-year implementation period

\footnotetext{
${ }^{2}$ See Whalley (2003) for a policy based discussion of these commitments and their possible impacts.
} 
(allowing more cities over time where foreign presence is allowed). Limits on allowable foreign participation (and ownership) are also to be progressively raised over time. ${ }^{3}$ Here, we do not explicitly consider services due to the added complexity of allowing for intertemporal intermediation, but instead limit ourselves to trade in goods, but the same themes that we emphasize in our analysis of trade in goods are in our view also likely apply to services liberalization.

Previous work on free trade zones [Hamada (1974), Rodriguez (1976), Hamilton and Svensson (1982), Miyagiwa (1986), Young and Miyagiwa (1987), Young (1987, 1992), Din (1994)] assesses the implications of zones of fixed size in the presence of existing distortions (e.g. tariffs, production taxes, access to foreign capital, unemployment, subsidies in import competing sectors) and the general conclusions on the welfare effects of free trade zones are mixed. Hamada (1974) assumes that tariffs on final goods prevailing in the rest of the economy are removed when a free trade zone is formed and shows that increased foreign investment in such a zone reduces national income. Hamilton and Svensson (1982) extend Hamada's model to study welfare effects of capital inflows either into the free trade zone or into the tariff zone and also conclude that both types of capital flow will lower the host country's welfare. In the presence of Harris-Todaro urban unemployment, Young and Miyagiwa (1987) show that the national income of the host country will increase as a result of the elimination of tariffs on imported intermediate inputs in the free trade zone. Young (1992) derives conditions for optimal wage and taxation policies for the free trade zone in the presence of unemployment. Din (1994) assumes that there is a non-traded intermediate good sector

\footnotetext{
${ }^{3}$ This is principally the vehicle used for liberalization in telecoms.
} 
and showes that increased foreign investment in the free trade zone can generate increase national income.

Our approach and interest differs from this literature in two ways. First, we consider cases where the size (and hence the border) of the free trade zone can be varied inside the economy. Second, we numerically evaluate the welfare implications of increasing the size of free trade zones and compare this to more conventional forms of trade liberalization such as a reduction in a national tariff rather than assessing the theoretically implications of forming free trade zones and seeking general qualitative results.

In what follows, we evaluate the welfare impacts of two types of trade policy changes under a treatment where they have observationally equivalent impacts in the sense of implied identical changes in trade volumes. To do this, we calibrate a numerical general equilibrium trade model of a small open economy to a base case free trade equilibrium data set. We then introduce both a free trade zone and a tariff zone into a conventional model and compare the outcome to that associated with the introduction of a trade volume equivalent national tariff. In the first experiment, while the tariff applies to international trade for only a portion of the economy also to trade internally between the free trade and protected zones. Subsequent trade policy changes reflect changes in the size of the free trade zone while the tariff rate in the tariff zone remains unchanged. In more conventional analysis, the tariff applies only at the national border and the rate is varied.

The numerical simulations we report show that the welfare changes of observationally equivalent trade policy changes differ greatly across the two cases (by 
factors of over 2). There is larger loss from the first type of intervention, reflecting both the use of a higher tariff rate on a smaller portion of trade, and the introduction of distortions across the divide between the free trade zone and the rest of the economy. We also explore the size of these differences both for pure exchange economies and models with production. Larger differences in effects occur in the latter case due to added distortions of the location of mobile factors across the two zones.

We conclude from our analysis that if trade liberalization is achieved through geographical expansion of free trade zones, policy analyzes which study such liberalization in national tariff equivalent terms can be highly misleading. Although more complex intertemporal and spatial models are needed to study the services liberalizations associated with Chinese WTO accession (banking, telecom, transportation), our analysis nonetheless suggests that analyzing liberalization of this form in tariff equivalent terms (as is typically done in the modelling literature equally) seems likely not to be a satisfactory way to proceed.

The rest of the paper is organized as follows. Section 2 describes a pure exchange economy model which permits the analysis of trade liberalization through geographical expansion of free trade zones. Section 3 extends the model to a production case. Section 4 performs numerical experiments to compare the welfare impacts of the two types of observationally equivalent trade liberalization discussed above. Section 5 concludes the paper. 


\section{A Single-Country Pure Exchange Economy With Both External and Movable Internal Barriers to Trade}

We consider a simple single-country pure exchange trade model with both international barriers to trade and internally movable barriers and fixed endowments of traded goods. The latter define a zone in which free international trade can occur, while trade between the zone and the rest of the economy involves the same tariff as applies to international trade. For simplicity we exclude non-traded goods from the analysis.

We assume that the country is divided into two zones, a free trade zone and a tariff zone. No tariffs apply in the free trade zone, while in the tariff zone there are ad valorem tariffs both on international trade and trade between the zones. To simplify matters, we treat the relative size of the two zones as being represented by the relative endowments of goods in each zone expressed in proportional terms. Thus, if the economy wide endowment is 10 units of good 1 and 20 units of good 2, and consumers in the free trade zone have 6 units of good 1 and 12 units of good 2, while those in the tariff zone have 4 and 8 units, the tariff zone is treated as covering $40 \%$ of the whole country.

Because we allow the relative size of the two zones to vary throughout the whole country, it further simplifies things to assume all consumers have identical homothetic preferences, and hence in both zones. We also normalize the size of the whole economy to 1 . In the example above, the sizes of the free trade and tariff zones are 0.6 and 0.4 respectively.

If $Y_{i}$ defines the aggregate endowment of good $i$ for the whole economy, and $\lambda$ is the size of the tariff zone (and $(1-\lambda)$ of the free trade zone), the aggregate endowments of goods in each zone are given by: 


$$
Y_{i}^{T}=\lambda Y_{i} \quad \text { and } \quad Y_{i}^{F}=(1-\lambda) Y_{i} \quad(i=1, \ldots, N) ; \quad 0 \leq \lambda \leq 1
$$

where superscript $T$ stands for the tariff zone and $F$ for the free trade zone.

To facilitate welfare analysis of alternative trade policies, we assume that the relative sizes of the free trade and tariff zones also reflect the relative sizes of the population in the zones. There are therefore $\lambda$ and $1-\lambda$ consumers in the tariff and free trade zones respectively, and $\lambda$ can change. We further assume that the aggregate endowments of each good in each zone are evenly distributed.

We assume for simplicity that all consumers have the identical CES preferences:

$$
U=\left[\sum_{i}\left(\alpha_{i}\right)^{\frac{1}{\sigma}}\left(X_{i}\right)^{\frac{\sigma-1}{\sigma}}\right]^{\frac{\sigma}{\sigma-1}} \quad(i=1, \ldots, N)
$$

where $\alpha_{i}$ is the consumption share of $\operatorname{good} i ; X_{i}$ is the demand for good $i ; \sigma$ is the elasticity of substitution. In this economy, utility-maximizing demands for goods depend upon the amount of income spent in each zone.

Since consumer prices differ across the zones, we write the aggregate demands in each zone as:

$$
X_{i}^{j}=\frac{\alpha_{i} I^{j}}{\left(P_{i}^{j}\right)^{\sigma} \sum_{i} \alpha_{i}\left(P_{i}^{j}\right)^{1-\sigma}} \quad(i=1, \ldots, N) ; \quad(j=F, T)
$$

where $X_{i}^{j}$ is the aggregate demand for good $i$ in zone $j, I^{j}$ is the income spent in zone $j$, and $P_{i}^{j}$ is the price of good $i$ in zone $j$.

The income in each zone, $I^{j}$, is given by:

$$
I^{F}=\sum_{i=1}^{N} P_{i}^{j} y_{i}^{F}+\gamma^{F} R \quad \text { and } \quad I^{T}=\sum_{i=1}^{N} P_{i}^{j} y_{i}^{T}+\gamma^{T} R
$$


where $\gamma^{j}$ denotes the share of national tariff revenue $\mathrm{R}$ collected in the tariff zone accruing to zone $j ; \sum_{j=F, T} \gamma^{j}=1, \quad \gamma^{j} \geq 0 .{ }^{4}$ Hence, the aggregate demand of good $\mathrm{i}$ for the whole economy is the sum of the aggregate demands in each zone:

$$
X_{i}=X_{i}^{F}+X_{i}^{T} \quad(i=1, \ldots, N)
$$

Defining the net trades of each good in the tariff zone as $M_{i}^{T}=X_{i}^{T}-Y_{i}^{T}$ $(i=1, \ldots, N) ; P_{i}^{W}$ as the world price of $\operatorname{good} i$; and $t_{i}$ as the tariff on good $I$; the national tariff revenue, $R$, is given by:

$$
R=\sum t_{i} P_{i}^{W} \max \left(M_{i}^{T}, 0\right)
$$

The aggregate net import of each good for the whole country, $M_{i}$, is given by the sum of net imports for each good entering each zone:

$$
M_{i}=\sum_{j} M_{i}^{j} \quad(i=1, \ldots, N) ; \quad(j=F, T)
$$

Since the country is modelled as a small open price-taking economy with no nontraded goods, it is simple to characterize an equilibrium for that formulation. Given world prices of goods, any excess demands for goods are absorbed by imports from (or exports to) the world market. Trade balance is implied by Walras' Law, which automatically follows from utility maximizing behaviour subject to budget constraints. Given $\lambda$, an equilibrium for this economy can also be easily computed. Alternatively, given a target tariff revenue $\mathrm{R}^{*}$ and a tariff rate $\mathrm{t}$ in the tariff zone, $\lambda$ can be endogenously determined as the relative size of the two zones needed to meet the revenue requirement and the tariff rate.

\footnotetext{
${ }^{4}$ Our numerical experiments in Section 4 assume that the tariff revenue collected in the tariff zone is only distributed to that zone. In this case, $\gamma^{F}=0$ and $\gamma^{T}=1$.
} 


\section{Figure 1: Movable Tariff and Free Trade Zones in a Small Open Price-taking Economy}

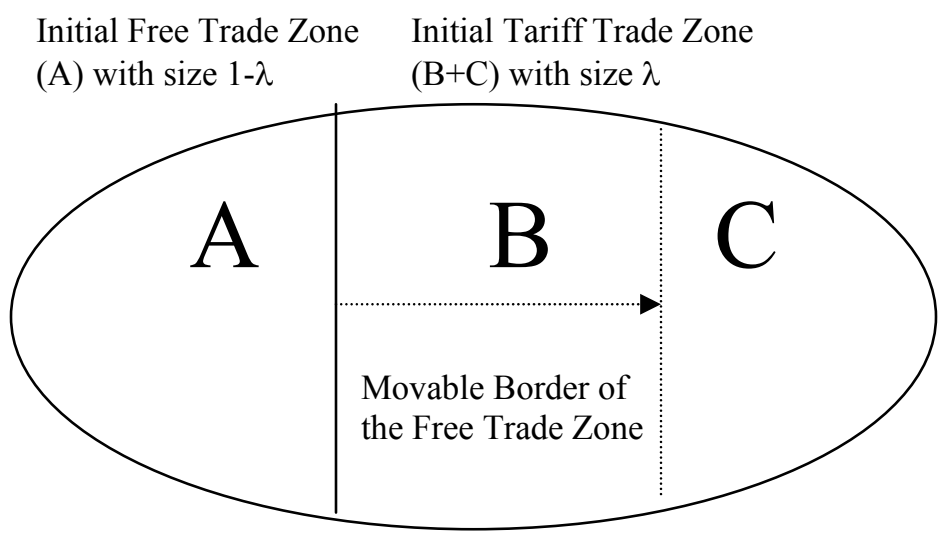

Trade liberalization in this economy can involve the geographical expansion of the free trade zone, a change in the tariff rate, or some combination of these. Area A in Figure 1 represents an initial free-trade zone and area $\mathrm{B}$ plus $\mathrm{C}$ an initial tariff zone. If we increase the size of the free trade zone from $1-\lambda$ to $1-\lambda$ ' for a given tariff rate (where $\lambda$ $>\lambda$ ), the size of the free trade zone increases to area A plus B while the tariff zone shrinks to area C. Since we assume the relative size of the zones also reflects the relative sizes of populations, under the change in the size of the free trade zone to $1-\lambda$ ', there are $1-\lambda, \lambda-\lambda^{\prime}$ and $\lambda^{\prime}$ consumers in area $\mathrm{A}, \mathrm{B}$ and $\mathrm{C}$ respectively. The only welfare changes for consumers in areas $\mathrm{A}$ and $\mathrm{C}$ arise from income effects as aggregate tariff revenues change, since after the geographical liberalization Area $A$ is still in the free trade zone and Area $\mathrm{C}$ is still in the tariff zone. Welfare changes for consumers in Area B result 
both from tariff revenue income effects but also from effects of price changes in moves from the tariff zone to the free trade zone.

To evaluate welfare impacts on consumers located in each of these areas, we first compute a general equilibrium before and after a trade policy change (i.e. such as the change from $\lambda$ to $\lambda$ ' respectively) and obtain consumption of each good in both the free trade and tariff zones before and after the trade policy change. Since endowments are evenly distributed within each zone and the relative sizes of zones reflect relative population sizes, we can easily compute consumption before and after liberalization in each of the areas (A, B and C). We can then compute Hicksian money metric welfare measures of the welfare changes for consumers located in each of these 3 areas. The welfare change for the whole economy is then computed by summing these money metric measurements which we then express as a $\%$ of the economy-wide pre-change income. 


\section{A Production Economy Model Allowing For Both External and $\underline{\text { Internal Barriers to Trade }}$}

The pure exchange economy in the previous section can be extended to a with production case by specifying a production technology, and again considering a small open economy with both international barriers to trade and movable internal barriers for a free trade zone. Our production economy in this case consists of two factors of production, one being a mobile factor and the other immobile. The immobile factor is specific for each sector in each zone while the mobile factor can move across sectors and between zones. We assume that the country is again divided into a free trade zone and a tariff zone. There are no international trade restrictions in the free trade zone while there are ad valorem tariffs in the tariff zone both on international trade and trade between the zones. As the free trade zone changes in size, the amount of the fixed factor in the zone correspondingly changes.

The relative size of the two zones in this case is given by the endowments of the immobile factors in each zone expressed once again in simple proportional terms. For instance, if we assume that the economy wide endowments of the sector specific immobile factor for sector 1 and sector 2 are 10 and 20 units respectively, if the free trade zone has 6 units of immobile factor in sector 1 and 12 units in sector 2, while the tariff zone 4 and 8 units are involved, the tariff zone is treated as $40 \%$ of the economy. Under this treatment, we can again normalize the size of the whole economy to 1 so that the sizes of the tariff and free trade zones are 0.4 and 0.6 respectively. 
Let $\bar{E}_{i}$ denote the economy-wide endowment of the immobile factor in sector $i$ producing good $i$. The endowments of fixed factor located in each zone are then given by:

$$
\bar{E}_{i}^{T}=\lambda \bar{E}_{i} \quad \text { and } \quad \bar{E}_{i}^{F}=(1-\lambda) \bar{E}_{i} \quad(i=1, \ldots, N) ; \quad 0 \leq \lambda \leq 1
$$

where the superscripts $T$ stands for the tariff zone and $F$ for the free trade zone and, $\lambda$ is again the size of the tariff zone and $(1-\lambda)$ is the size of the free trade zone.

We assume technology in each sector is decreasing returns to scale in the mobile factor:

$$
Y_{i}^{j}=A_{i}^{j}\left(F_{i}^{j}\right)^{\theta_{i}} \quad(i=1, \ldots, N) ; \quad(j=F, T)
$$

where $\theta_{i}<1$ and the superscript $j$ represents the zone-type and the subscript $i$ stands for the good-type, $Y_{i}^{j}$ is the output of good $i$ in zone $j$ and $A_{i}^{j}$ is a scale parameter in production, $F_{i}^{j}$ represents the mobile factor used in zone $j$ for production of good $i$. Rents accrue to the fixed factor $\bar{E}_{i}^{j}$.

Profit maximization yields the requiring demand functions for the mobile factor in each sector in each zone as:

$$
F_{i}^{j}=\frac{\theta_{i} P_{i}^{j} Y_{i}^{j}}{R^{j}} \quad(i=1, \ldots, N) ; \quad(j=F, T)
$$

where $P_{i}^{j}$ is the price of good $i$ in zone $j$ and $R^{j}$ is the price of the mobile labor in zone $\mathrm{j}$. Prices for the mobile factor differ across the zones because consumers take into account the different costs of goods in deciding where to locate and sell their factor endowments and consume goods (see below). 
As in Section 2, the relative sizes of the free trade and tariff zones also reflect the size of populations in the two zones. Aggregate endowments in each zone are again assumed evenly distributed, and consumers have identical CES preference as in Section 2. There are thus $\lambda$ and $1-\lambda$ consumers in the tariff and free trade zones respectively.

Income accruing in each zone now includes returns to the fixed factors owned by consumers located in that zone. Individual utility, demands and income can be again represented by equations (2), (3) and (4) respectively. The aggregate income and demands in each zone are given by equations (5) and (6) modified to include factor incomes, and the economy-wide demands and net imports of each good are again represented by equation (7) and (9) respectively.

A general equilibrium for this economy is characterized by prices of the mobile factor in the zones $\left(R^{F}\right.$ and $\left.R^{T}\right)$ such that given the sizes of tariff and free trade zones, $\lambda$ and $1-\lambda$, the following conditions hold:

1. The national market for the mobile factor clears:

$$
\sum_{j} \sum_{i} F_{i}^{j}=\bar{F} \quad(i=1, \ldots, N) ; \quad(j=F, T)
$$

2. Consumer price-adjusted returns to mobile factors across the zones are equalized:

$$
\frac{R^{F}}{P^{F}}=\frac{R^{T}}{P^{T}}
$$

where $P^{F}$ and $P^{T}$ are cost-of-living indices for consumers located in the free trade and tariff zones respectively.

This cost of living adjustment reflects the feature that mobile factor owners (e.g. labor) consume goods where they reside. In the CES case, these indices are given by: 


$$
P^{j}=\left(\sum_{i} \alpha_{i}\left(P_{i}^{j}\right)^{1-\sigma}\right)^{\frac{1}{1-\sigma}} \quad(j=F, T)
$$

where $\alpha_{i}$ is the consumption share of $\operatorname{good} i$ in preferences, $P_{i}^{j}$ is the price of good $i$ in zone $j$, and $\sigma$ is the elasticity of substitution.

In equilibrium, any excess demands for goods are absorbed by imports from (or exports to) the world market, and balanced trade is implied by Walras' Law.

As with the pure exchange case, we can evaluate the welfare impacts of introducing trade impact observationally equivalent tariff zones ( $\lambda$, and a tariff rate) and lower national tariffs with no free trade zone. We can also change the size of the tariff zone from $\lambda$ to $\lambda^{\prime}$ for a given tariff rate. As in Figure 1 in Section 2, we can consider increasing the size of the free trade zone to area A plus B, shrinking the tariff zone to area C. Since there is a production and mobile factor in this case, welfare impacts for areas A and $\mathrm{C}$ now not only reflect income effects as aggregate tariff revenues change and relative commodity price effects, but also from effects of the reallocation of the mobile factor. The welfare impact for area B will be larger in the with production case as it changes from being part of the tariff zone and becomes part of the free trade zone and the amount of the mobile factor used in the zone also changes. Free trade zones thus will also affect the spatial distribution of the mobile factor. Following a similar approach to that described in Section 2, we can compute welfare changes for consumers located in each of these areas for any given trade policy change, and sum the money metric measures to obtain the welfare change for the whole economy. We can also express such measures as a $\%$ of the economy-wide pre-policy -change income. 


\section{Results from Some Observationally Equivalent Numerical Policy}

\section{Experiments}

This section reports results from some numerical experiments performed using the equilibrium structures set out above. Our aim is to compare the welfare consequences of trade liberalization achieved through conventional national tariff reductions to those generated by geographical expansion of free trade zones. We evaluate the welfare impacts of these two types of trade policy under a treatment that they are constructed to be observationally equivalent in the sense of generating identical changes in trade volumes. We consider both pure exchange economy and production economy models.

Our aim is not to generate general qualitative results which we believe are not easily obtainable and are anyway not our main focus. Rather, we assess how far one might be misled by analyzing what is in reality zone-based liberalization but is represented instead in national tariff equivalent terms. Our numerical results inevitably depend on the model structure we use and the parameters we employ and are offered as suggestive rather than definitive. For that reason, we perform also sensitivity analysis on the cases we analyze. We use a simple example in which there are two goods, one being the exportable and the other the importable. 
Figure 2. Flow Chart Outlining the Procedures Used in Constructing Observationally Equivalent Numerical Experiments Comparing National and Zone Based Trade Policy Changes (Similar Procedures Used for Pure Exchange and With Production Cases)

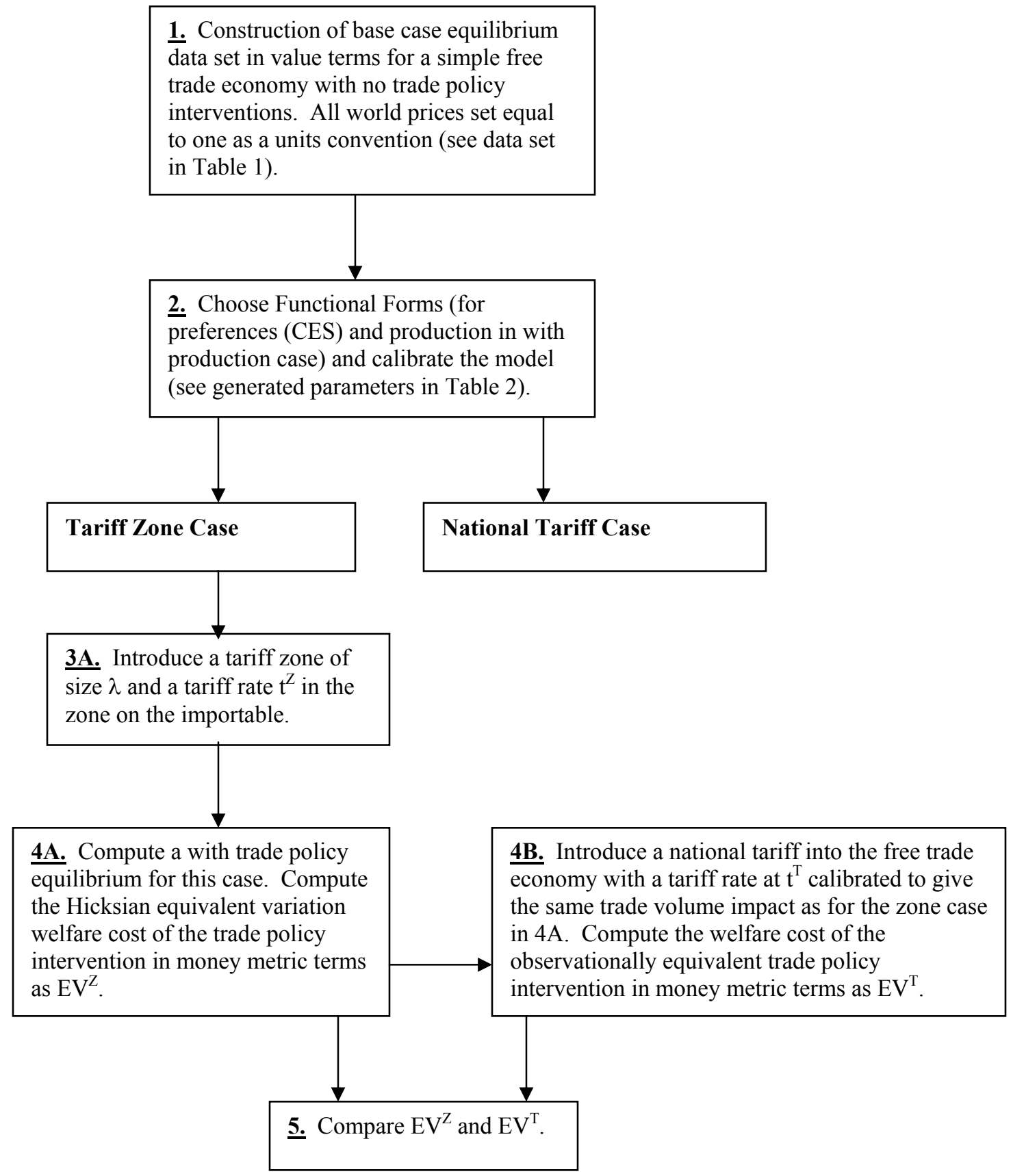


The procedures used for our numerical experiments are set out in the flowchart presented in Figure 2. We begin by calibrating a conventional single-country pricetaking trade model without trade policy interventions to a free trade base case data set. In the case of a pure exchange economy, the model is as described in Section 2, with the size of the tariff zone set equal to 0 (i.e. $\lambda=0$ ). For a production economy, the model is as described in Section 3, with the size of the tariff zone set equal to 0.

We evaluate the welfare impacts of two types of trade policy change. In the first case (the tariff zone case), we introduce a tariff zone of size $\lambda$ equal to 0.55 and a tariff rate $\mathrm{t}^{\mathrm{Z}}$ of 0.6 in the zone for the importable. We then compute a with zone equilibrium for this case, and compare it to the original free trade equilibrium to generate a money metric measure of welfare impact of the trade policy change of $\mathrm{EV}^{\mathrm{Z}}$. In the second case (the national tariff case), we introduce an observationally equivalent national tariff $\mathrm{t}^{\mathrm{T}}$ into the free trade calibrated model giving the same impact on trade volumes as in the tariff zone case. This trade-impact equivalent national tariff rate is calculated to be about 0.3 for both pure exchange and with production cases. We then compute a money metric measure of the welfare impact of this intervention $\mathrm{EV}^{\mathrm{T}}$ and compare this to $\mathrm{EV}^{\mathrm{Z}}{ }^{5}$ Table 1 presents the base case data we use for our experiments, one for a pure exchange economy and the other for an economy with production. Table 2 gives the value parameters that are generated by calibration of the relevant model to data. We

\footnotetext{
${ }^{5}$ Our numerical experiments start from a free trade regime and consider two different trade policy interventions (i.e. a tariff zone case and a national tariff case) and compare their welfare impacts. Alternatively, we can also start from these two trade policy interventions and then consider trade liberalization and compare the welfare gains. In the tariff zone case, trade liberalization is achieved by expanding the sizes of the free trade zone. In the national tariff zone case, it is achieved by a conventional national tariff reduction.
} 
summarize the results for the two types of trade policy change in Tables 3 and 4 for the pure exchange and with production economies respectively. 
Table 1. Base Case Data Used to Represent A Free Trade Equilibrium for A Pure Exchange and A With Production Economy in Observationally Equivalent Numerical Trade Policy Experiments

\begin{tabular}{|c|c|c|c|}
\hline \multicolumn{2}{|c|}{$\begin{array}{l}\text { A. Value Data for Pure Exchange } \\
\text { Economy }\end{array}$} & \multicolumn{2}{|c|}{ B. Value Data for Production Economy } \\
\hline $\begin{array}{l}\text { Consumption of Importable } \\
\text { Commodity }\end{array}$ & 180 & $\begin{array}{l}\text { Consumption of Importable } \\
\text { Commodity }\end{array}$ & 180 \\
\hline $\begin{array}{l}\text { Endowment of Importable } \\
\text { Commodity }\end{array}$ & 100 & $\begin{array}{l}\text { Production of Importable } \\
\text { Commodity }\end{array}$ & 100 \\
\hline \multirow[t]{2}{*}{ Imports } & 80 & Imports & 80 \\
\hline & & $\begin{array}{l}\text { Use of Mobile Factor in Producing } \\
\text { the Importable Commodity }\end{array}$ & 60 \\
\hline $\begin{array}{l}\text { Consumption of Exportable } \\
\text { Commodity }\end{array}$ & 70 & $\begin{array}{l}\text { Use of Immobile Factor in } \\
\text { Producing the Importable } \\
\text { Commodity }\end{array}$ & 72 \\
\hline $\begin{array}{l}\text { Endowment of Exportable } \\
\text { Commodity }\end{array}$ & 150 & & \\
\hline \multirow[t]{2}{*}{ Exports } & 80 & $\begin{array}{l}\text { Consumption of Exportable } \\
\text { Commodity }\end{array}$ & 70 \\
\hline & & $\begin{array}{l}\text { Production of Exportable } \\
\text { Commodity }\end{array}$ & 150 \\
\hline World Price of Importable & 1.0 & Exports & 80 \\
\hline \multirow[t]{10}{*}{ World Price of Exportable } & 1.0 & $\begin{array}{l}\text { Use of Mobile Factor in Producing } \\
\text { the Exportable Commodity }\end{array}$ & 100 \\
\hline & & $\begin{array}{l}\text { Use of Immobile Factor in } \\
\text { Producing the Exportable } \\
\text { Commodity }\end{array}$ & 100 \\
\hline & & Endowment of Mobile Factor & 160 \\
\hline & & $\begin{array}{l}\text { Endowment of Immobile Factor } \\
\text { Used in the Importable Sector }\end{array}$ & 72 \\
\hline & & $\begin{array}{l}\text { Endowment of Immobile Factor } \\
\text { Used in the Exportable Sector }\end{array}$ & 100 \\
\hline & & Price of Importable Commodity & 1.0 \\
\hline & & Price of Exportable Commodity & 1.0 \\
\hline & & Price of Mobile Factor & 1.0 \\
\hline & & $\begin{array}{l}\text { Price of Immobile Factor in the } \\
\text { Importable Sector }\end{array}$ & 1.0 \\
\hline & & $\begin{array}{l}\text { Price of Immobile Factor in the } \\
\text { Exportable Sector }\end{array}$ & 1.0 \\
\hline
\end{tabular}


Table 2. Model Parameter Values Generated by Calibration to Data in Table 1 and Used in Numerical Experiments

\begin{tabular}{|c|c|c|c|c|c|}
\hline \multicolumn{3}{|c|}{ A. Pure Exchange Economy Model } & \multicolumn{3}{|c|}{ B. Production Economy Model } \\
\hline \multicolumn{3}{|c|}{ Exogenous Parameters } & \multicolumn{3}{|c|}{ Exogenous Parameters } \\
\hline $\begin{array}{l}\text { Elasticity of } \\
\text { Substitution }(\sigma)\end{array}$ & & 1.5 & $\begin{array}{l}\text { Elasticity of } \\
\text { Substitution }(\sigma)\end{array}$ & & 1.5 \\
\hline \multicolumn{3}{|c|}{ Calibrated Parameters } & \multicolumn{3}{|c|}{ Calibrated Parameters } \\
\hline & Exportable & Importable & & Exportable & Importable \\
\hline \multirow[t]{3}{*}{$\begin{array}{l}\text { Consumption } \\
\text { Shares }\left(\alpha_{i}\right)\end{array}$} & 0.2 & 0.8 & $\begin{array}{l}\text { Consumption } \\
\text { Shares }\left(\alpha_{i}\right)\end{array}$ & 0.2 & 0.8 \\
\hline & & & $\begin{array}{l}\text { Scale Parameter } \\
\text { in Production } \\
\left(A_{i}\right)\end{array}$ & 1.5 & 1.5 \\
\hline & & & $\begin{array}{lr}\text { Mobile Factor } \\
\text { Share in } \\
\text { Production }\left(\theta_{i}\right)\end{array}$ & 0.6 & 0.4 \\
\hline
\end{tabular}

Table 3. Welfare Effects of Trade Policy Changes with Observationally Equivalent Responses in Export/Import Volumes

(1) Tariff Zone Case (2) National Tariff Case Welfare Differential: (1)/(2)

\begin{tabular}{lccc}
\hline & $\begin{array}{c}\text { Money Metric Welfare Impacts } \\
\text { (Hicksian EV as \% of Basecase Income) }\end{array}$ & \\
Pure Exchange Economy & -1.7 & -1.0 & 1.7 \\
\hline Production Economy & -3.4 & -1.5 & 2.3 \\
\hline
\end{tabular}

Table 3 reports the welfare impacts of these policy interventions in terms of Hicksian money metric welfare measures. In the pure exchange case, the welfare costs in imposing a geographical restrictive tariff scheme (the tariff zone case) are almost 2 times 
larger than those from a conventional national tariff with observationally equivalent trade effects (the national tariff case). This reflects both the use of a higher tariff rate on a smaller portion of trade, and the introduction of distortions across the divide between the free trade zone and the tariff zone when modeling the tariff zone case. On the other hand, there is a relatively lower national tariff applying at the national border and there are no internal distortions within the country. Thus, welfare impacts of observationally equivalent trade policy changes differ across the two cases.

For the production economy, welfare differences from the two cases are even larger, with the welfare costs from the tariff zone case more than 2 times larger than those in the national tariff case. This reflects the added distortion of the location of the mobile factor across the free trade and tariff zones in the model with production. In this case, trade liberalization through geographical expansion of the free trade zone not only eliminates distortions of trade in goods across the free trade zone and the tariff zone and across the national border, but also removes distortions of mobile factor allocations between the free trade zone and the tariff zone. Welfare gains from such liberalizations are thus typically larger than those from conventional national tariff reductions, if both types of liberalization are constructed to generate the same response in trade volume.

We have performed sensitivity analyses for these numerical experiments to analyze how the exogenous choice of the elasticity of substitution affects the differential welfare cost of these two types of trade policy changes. Table 4 reports simulation results for a range of elasticities of substitution for both pure exchange and production economies. 
Table 4. Sensitivity Analyses of Welfare Effects of Trade Policy Changes

with Observationally Equivalent Responses in Export/Import Volumes

to Different Values of Elasticities of Substitution

\begin{tabular}{|c|c|c|c|c|c|}
\hline \multirow{3}{*}{$\begin{array}{l}\text { Money Metric Welfare Impacts } \\
\text { (Hicksian EV as \% of Income) }\end{array}$} & \multicolumn{5}{|c|}{ Elasticity of Substitution } \\
\hline & $\underline{0.5}$ & $\underline{0.75}$ & $\underline{1.5}$ & $\underline{2.0}$ & $\underline{2.5}$ \\
\hline & & & ige Ec & & \\
\hline (1) Tariff Zone Case & -0.5 & -0.8 & -1.7 & -2.4 & -3.2 \\
\hline (2) National Tariff Case & -0.3 & -0.4 & -1.0 & -1.5 & -1.9 \\
\hline \multirow{2}{*}{$\begin{array}{l}\text { Welfare Differential: (1)/(2) } \\
\text { Money Metric Welfare Impacts } \\
\text { (Hicksian EV as \% of Income) }\end{array}$} & 1.7 & 1.7 & 1.7 & 1.7 & 1.6 \\
\hline & & & tion $\mathrm{E}$ & & \\
\hline (3) Tariff Zone Case & -2.4 & -2.6 & -3.4 & -3.9 & -4.6 \\
\hline (4) National Tariff Case & -1.0 & -1.1 & -1.5 & -1.9 & -2.3 \\
\hline Welfare Differential: (3)/(4) & 2.5 & 2.4 & 2.2 & 2.1 & 2.0 \\
\hline
\end{tabular}

The results with CES preferences indicate that a higher (lower) elasticity of substitution implies higher (lower) magnitudes of both own price and cross price elasticities, and these augment (lessen) the welfare impacts of price changes from trade interventions. In the pure exchange economy case, the welfare differential across cases is relatively insensitive to the choice of elasticity of substitution. Numerical experiments indicate that both cases have similar percentage increases (decreases) in welfare when a higher (lower) elasticity of substitution is used, resulting in a stable welfare differential. 
The production economy experiments indicate that the welfare differentials decrease (increase) mildly with higher (lower) elasticities of substitution.

The quantitative implications of these sensitivity analyses suggest similar results to those of the base case experiments. The welfare costs of imposing geographical restrictive schemes are substantially larger than imposing national tariffs. The welfare impacts of observationally equivalent trade liberalization through geographical expansion of free trade zones will likely be significantly larger than the liberalization through conventional national tariff reductions. Welfare differentials are larger in a production economy due to the added distortion of the location of mobile factor across the free trade and tariff zones. 


\section{Concluding Remarks}

This paper compares trade liberalization through the geographical expansion of free trade zones to that achieved by conventional national tariff reductions. Our analysis is motivated by the form that services liberalization with expansion of geographical coverage of services takes. Our results suggest that there are substantial differences between numerical policy analyses using conventional tariff-equivalent ad valorem modeling approach to evaluate the impacts of liberalizing geographical barriers and explicit modeling of such policies. Although more complex intertemporal and spatial models are needed to adequately study actual services liberalization (banking, telecom, transportation), our analysis clearly suggests that analyzing liberalizations of this form for economies such as China in tariff equivalent terms (as is typically done in the modelling literature equally) is probably not to be a satisfactory way to proceed. 


\section{$\underline{\text { Reference }}$}

Din, M. (1994), "Export Processing Zones and Backward Linkages", Journal of Development Economics 43: 369-385.

Hamada, K. (1974), "An Economic Analysis of the Duty-Free Zone", Journal of International Economics 4: 225-241.

Hamilton, C. and L. Svensson (1982), "On the Welfare Effects of a Duty-Free Zone", Journal of International Economics 13: 45-64.

Miyagiwa, K. (1986), "A Reconsideration of the Welfare Economics of a Free-Trade Zone", Journal of International Economics 21: 337-350.

Rodriguez, C.A. (1976), "A Note on the Economics of the Duty-Free Zone", Journal of International Economics 6: 385-388.

Whalley, J. and J. Shoven, (1992), "Applying General Equilibrium”, Cambridge University Press.

Whalley, J. (2003), "Liberalization in China's Key Service Sectors Following WTO Accession: Some Scenarios, and Issues of Measurement", NBER working paper: w10143.

Young, L. (1987), "Intermediate Goods and the Formation of Duty-Free Zones", Journal of Development Economics 25: 369-384.

Young, L. and K. Miyagiwa (1987), "Unemployment and the formation of duty-free zones", Journal of Development Economics 26: 397-405.

Young, L. (1992), "Unemployment and the Optimal Export-processing Zone", Journal of Development Economics 37: 369-385. 


\section{CESifo Working Paper Series}

(for full list see www.cesifo.de)

1080 Andreas Haufler and Michael Pflüger, Market Structure and the Taxation of International Trade, November 2003

1081 Jonas Agell and Helge Bennmarker, Endogenous Wage Rigidity, November 2003

1082 Fwu-Ranq Chang, On the Elasticities of Harvesting Rules, November 2003

1083 Lars P. Feld and Gebhard Kirchgässner, The Role of Direct Democracy in the European Union, November 2003

1084 Helge Berger, Jakob de Haan and Robert Inklaar, Restructuring the ECB, November 2003

1085 Lorenzo Forni and Raffaela Giordano, Employment in the Public Sector, November 2003

1086 Ann-Sofie Kolm and Birthe Larsen, Wages, Unemployment, and the Underground Economy, November 2003

1087 Lars P. Feld, Gebhard Kirchgässner, and Christoph A. Schaltegger, Decentralized Taxation and the Size of Government: Evidence from Swiss State and Local Governments, November 2003

1088 Arno Riedl and Frans van Winden, Input Versus Output Taxation in an Experimental International Economy, November 2003

1089 Nikolas Müller-Plantenberg, Japan’s Imbalance of Payments, November 2003

1090 Jan K. Brueckner, Transport Subsidies, System Choice, and Urban Sprawl, November 2003

1091 Herwig Immervoll and Cathal O'Donoghue, Employment Transitions in 13 European Countries. Levels, Distributions and Determining Factors of Net Replacement Rates, November 2003

1092 Nabil I. Al-Najjar, Luca Anderlini \& Leonardo Felli, Undescribable Events, November 2003

1093 Jakob de Haan, Helge Berger and David-Jan Jansen, The End of the Stability and Growth Pact?, December 2003

1094 Christian Keuschnigg and Soren Bo Nielsen, Taxes and Venture Capital Support, December 2003 
1095 Josse Delfgaauw and Robert Dur, From Public Monopsony to Competitive Market. More Efficiency but Higher Prices, December 2003

1096 Clemens Fuest and Thomas Hemmelgarn, Corporate Tax Policy, Foreign Firm Ownership and Thin Capitalization, December 2003

1097 Laszlo Goerke, Tax Progressivity and Tax Evasion, December 2003

1098 Luis H. B. Braido, Insurance and Incentives in Sharecropping, December 2003

1099 Josse Delfgaauw and Robert Dur, Signaling and Screening of Workers' Motivation, December 2003

1100 Ilko Naaborg, Bert Scholtens, Jakob de Haan, Hanneke Bol and Ralph de Haas, How Important are Foreign Banks in the Financial Development of European Transition Countries?, December 2003

1101 Lawrence M. Kahn, Sports League Expansion and Economic Efficiency: Monopoly Can Enhance Consumer Welfare, December 2003

1102 Laszlo Goerke and Wolfgang Eggert, Fiscal Policy, Economic Integration and Unemployment, December 2003

1103 Nzinga Broussard, Ralph Chami and Gregory D. Hess, (Why) Do Self-Employed Parents Have More Children?, December 2003

1104 Christian Schultz, Information, Polarization and Delegation in Democracy, December 2003

1105 Daniel Haile, Abdolkarim Sadrieh and Harrie A. A. Verbon, Self-Serving Dictators and Economic Growth, December 2003

1106 Panu Poutvaara and Tuomas Takalo, Candidate Quality, December 2003

1107 Peter Friedrich, Joanna Gwiazda and Chang Woon Nam, Development of Local Public Finance in Europe, December 2003

1108 Silke Uebelmesser, Harmonisation of Old-Age Security Within the European Union, December 2003

1109 Stephen Nickell, Employment and Taxes, December 2003

1110 Stephan Sauer and Jan-Egbert Sturm, Using Taylor Rules to Understand ECB Monetary Policy, December 2003

1111 Sascha O. Becker and Mathias Hoffmann, Intra-and International Risk-Sharing in the Short Run and the Long Run, December 2003

1112 George W. Evans and Seppo Honkapohja, The E-Correspondence Principle, January 2004 
1113 Volker Nitsch, Have a Break, Have a ... National Currency: When Do Monetary Unions Fall Apart?, January 2004

1114 Panu Poutvaara, Educating Europe, January 2004

1115 Torsten Persson, Gerard Roland, and Guido Tabellini, How Do Electoral Rules Shape Party Structures, Government Coalitions, and Economic Policies? January 2004

1116 Florian Baumann, Volker Meier, and Martin Werding, Transferable Ageing Provisions in Individual Health Insurance Contracts, January 2004

1117 Gianmarco I.P. Ottaviano and Giovanni Peri, The Economic Value of Cultural Diversity: Evidence from US Cities, January 2004

1118 Thorvaldur Gylfason, Monetary and Fiscal Management, Finance, and Growth, January 2004

1119 Hans Degryse and Steven Ongena, The Impact of Competition on Bank Orientation and Specialization, January 2004

1120 Piotr Wdowinski, Determinants of Country Beta Risk in Poland, January 2004

1121 Margarita Katsimi and Thomas Moutos, Inequality and Redistribution via the Public Provision of Private Goods, January 2004

1122 Martin Peitz and Patrick Waelbroeck, The Effect of Internet Piracy on CD Sales: CrossSection Evidence, January 2004

1123 Ansgar Belke and Friedrich Schneider, Privatization in Austria: Some Theoretical Reasons and First Results About the Privatization Proceeds, January 2004

1124 Chang Woon Nam and Doina Maria Radulescu, Does Debt Maturity Matter for Investment Decisions?, February 2004

1125 Tomer Blumkin and Efraim Sadka, Minimum Wage with Optimal Income Taxation, February 2004

1126 David Parker, The UK's Privatisation Experiment: The Passage of Time Permits a Sober Assessment, February 2004

1127 Henrik Christoffersen and Martin Paldam, Privatization in Denmark, 1980-2002, February 2004

1128 Gregory S. Amacher, Erkki Koskela and Markku Ollikainen, Deforestation, Production Intensity and Land Use under Insecure Property Rights, February 2004

1129 Yin-Wong Cheung, Javier Gardeazabal, and Jesús Vázquez, Exchange Rate Dynamics: Where is the Saddle Path?, February 2004

1130 Alberto Alesina and Guido Tabellini, Bureaucrats or Politicians?, February 2004 
1131 Gregory S. Amacher, Erkki Koskela, and Markku Ollikainen, Socially Optimal Royalty Design and Illegal Logging under Alternative Penalty Schemes, February 2004

1132 David M. Newbery, Privatising Network Industries, February 2004

1133 Charles Yuji Horioka, The Stagnation of Household Consumption in Japan, February 2004

1134 Eiji Fujii, Exchange Rate Pass-Through in the Deflationary Japan: How Effective is the Yen's Depreciation for Fighting Deflation?, February 2004

1135 Mark M. Spiegel and Nobuyoshi Yamori, Determinants of Voluntary Bank Disclosure: Evidence from Japanese Shinkin Banks, Febrary 2004

1136 Robert Dekle and Kenneth Kletzer, Deposit Insurance, Regulatory Forbearance and Economic Growth: Implications for the Japanese Banking Crisis, February 2004

1137 Takatoshi Ito and Kimie Harada, Bank Fragility in Japan, 1995-2003, February 2004

1138 Kunio Okina and Shigenori Shiratsuka, Policy Duration Effect under Zero Interest Rates: An Application of Wavelet Analysis, February 2004

1139 Francine D. Blau and Lawrence M. Kahn, Do Cognitive Test Scores Explain Higher U.S. Wage Inequality?, February 2004

1140 Michael Rauscher, Economic Growth and Tax-Competing Leviathans, February 2004

1141 Ernst Fehr and Jean-Robert Tyran, Money Illusion and Coordination Failure, February 2004

1142 Ingo Vogelsang, Network Utilities in the U.S. - Sector Reforms without Privatization, March 2004

1143 Marc-Andreas Muendler, Estimating Production Functions When Productivity Change is Endogenous, March 2004

1144 Sascha O. Becker, Samuel Bentolila, Ana Fernandes, and Andrea Ichino, Job Insecurity and Children's Emancipation, March 2004

1145 Pascalis Raimondos-Møller and Alan D. Woodland, Non-Preferential Trading Clubs, March 2004

1146 Robert Fenge and Matthias Wrede, EU Regional Policy: Vertical Fiscal Externalities and Matching Grants, March 2004

1147 Chi-Yung Ng and John Whalley, Geographical Extension of Free Trade Zones as Trade Liberalization: A Numerical Simulation Approach, March 2004 